\title{
Creationism 'Ark' trial opens in Australia
}

[SYDNEY] The running battle between creationists, scientists and educators over the teaching of evolution in schools took a new turn this week with the opening of a trial in Sydney, Australia, in which a leading geologist is claiming that the public has been deliberately misled by statements about what some are claiming to be the petrified remains of Noah's Ark.

The creationist dispute has been raging ever since the infamous 'monkey trial' in Tennessee 72 years ago, at which John Scopes was convicted for teaching evolution. The Australian case represents the culmination of highly publicized confrontations that took place in 1992 between Ian Plimer, head of Earth sciences at the University of Melbourne, and Allen Roberts, a proponent of creationism.

Plimer says that Roberts made false claims at lectures about 'Noah's Ark' - a boat-shaped structure found at Akyayla in the mountains of eastern Turkey, $20 \mathrm{~km}$ southeast of Mount Ararat. Plimer wants the federal court to restrain Roberts from repeating his claims and to stop sales of tapes of the lectures. The tapes were being sold by Roberts's support group, Ark Search Association Incorporated.

The case is the first time that the relative credibility of science and creationism have been disputed under legislation designed to protect consumers against misleading or deceptive commercial conduct. The thrust of Plimer's case lies in the legal responsibility of a trader not to make false or unprovable claims.

Plimer says he has been motivated to pursue Roberts partly by the results of surveys of new students in the science faculties of Australian universities which show that up to one in five holds creationist views. Australia has a growing number of private schools run on fundamentalist Christian principles, and these have criticized Plimer,

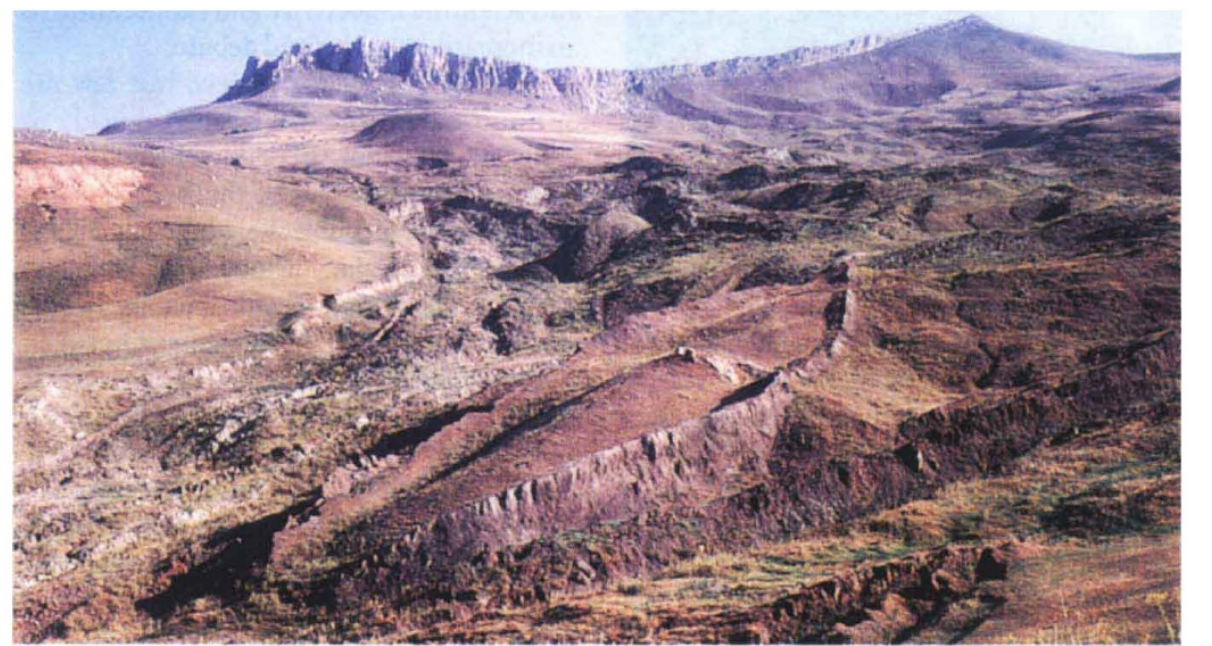

Noah's Ark? Claims about this geological formation near Mount Ararat, Turkey, form part of the case.

on the grounds of supporting freedom of speech, for not agreeing with their teaching alternative 'theories' of life.

Roberts claims that he and associates found 'scientific' evidence of Noah's Ark in the boat-shaped structure. It has been known for at least 40 years that the structure exhibits the dimensions of the Ark as recorded in Genesis. In lectures, publications and tapes sold to support an expedition for further 'investigation', Roberts has strongly suggested that verification - he has never talked of 'proof' - of the structure's origins came from the presence of the ribs of a boat, petrified wood, iron rivets, a deer's antlers, fossilized animal dung (coprolites) and stone anchors.

During a contentious lecture tour by Roberts in 1992, police were called to eject Plimer and other scientists seeking to challenge his statements. Roberts was described by Ark Search as its "archaeological research consultant".

Rather than being asked to decide on the relative claims of science and creationism about the nature of the Turkish structure, Judge Ron Sackville will assess claims made by Plimer and David Fasold, a US marine salvager, against Roberts and Ark Search on commercial grounds. The case is a civil trial, with applicants and respondents arguing their case before the judge, but without a jury. In early hearings before witnesses were called, the judge indicated that he would look closely at assertions that "activities" at the site by either Plimer or Roberts were "scientific in character".

Fasold was a firm believer in the existence of the Ark, and published a book describing his views in 1988. He alleges that Roberts infringed his copyright, as a result of which he "suffered loss and damage". He now says the structure is not the Ark, but what the ancient residents of the Euphrates Valley thought to be so.

NATURE|VOL. 386 10 APRIL 1997
On one of several field trips to Turkey, Plimer studied the Akyayla site in 1994 . He concluded that it is an unremarkable formation of folded and weathered ophiolite, partly covered in mud, and suggested that it is between 110 million and 120 million years old. In a book published that year, he accused creationists of "scientific fraud" in promoting the site as the Ark.

Plimer suggests that Roberts and Ark Search have made misleading claims about their involvement in gathering data about the 'Ark' in a scientific manner. Plimer also challenges the way in which Roberts justified his claims to scientific expertise by citing a doctorate in Christian education which, claims Plimer, "is from an institution of low academic repute and has no relevance to archaeological or scientific knowledge".

Roberts describes himself as a graduate of Freedom University, a correspondence Bible college which was revealed in 1992 to have little presence beyond sharing a mailbox with the Maitland Bible Church in Orlando, Florida.

Roberts and Ark Search deny all the claims and damages. As part of their defence, they claim Fasold "formed an association" with Ron Wyatt, with whom he "cooperated and shared information" in studying the Ark site. Wyatt, from Nashville, Tennessee, described himself in 1989 as having been officially recognized by the Turkish government as "the archaeologist who discovered Noah's Ark".

On the advice of their lawyers, Roberts and Ark Search have declined to provide interviews or statements "before or during the trial".

Fasold and Plimer are calling four witnesses. Two are Australian palaeontologists, Alex Ritchie of the Australian Museum in Sydney and Neil Archbold of Deakin University in Melbourne. One, Edwin Byford, is a theologian, and the fourth, Eugenie Scott, is director of the National Center for Science Education in Berkeley, California, and a long-term campaigner against the teaching of 'creation science' in American schools.

The trial is scheduled to last three weeks, and the costs to the loser will be high. Plimer estimates that the case is already costing him A $\$ 500,000$ (US\$390,000), for which he has had to sell his house.

Six days before the trial, Ark Search went into liquidation, complicating an already difficult case for Plimer to argue within commerciallaw.

The outcome of the trial is likely to have a direct impact on another case in which Plimer is being sued by Roberts in the Supreme Court of Victoria for alleged defamation in public and in the media.

PeterPockley 